\title{
BREAD BAKING PROCESS ENERGY REQUIREMENTS AS AFFECTED BY OVEN BELT SPEED AND TYPE OF BREADS
}

\author{
Islam F. El-Adly*, Adel H. Bahnasawy**, \\ Samir A. Ali** and El-Sayed G. Khater***
}

ABSTRACT

The main aim of the present work is to study and evaluate baking process energy requirements which considered the most consumable energy of bread baking stages. This was achieved by determining the moisture content, baking time, productivity and three types of energy (electrical, human and thermal) at four different belt speeds for two different types of baladi-breads, namely Magr and Mawi. Those four speedswere1.18, 1.97, 2.40 and3.55 $\mathrm{ms}^{-1}$. The results show that initial moisture content of dough was $42.12 \%$ for Magr but $62.02 \%$ for Mawi, while after baking it were 24.32, 24.61, 26.09 and 29.25\% for Magr and 34.25, 39.50, 40.98 and $41.66 \%$ for Mawi at each speed, respectively. The results also indicated that the average baking time were 1.65, 1.10, 0.86 and 0.81 minkg${ }^{1}$ andproductivity were 36.54, 54.63, 70.11and73.80 $\mathrm{kghr}^{-1}$ for Magr Baladi bread while the average baking time were 1.87, 1.13, 0.89and 0.84 minkg $^{-1}$ andproductivity were 32.62, 53.10, 67.48and $71.33 \mathrm{kghr}^{-1}$ for Mawi baladi-bread at each speed, respectively. The specific energy requirements consumed were3.57, 2.92, 2.54 and $1.93 \mathrm{kWhkg}^{-1}$ for Magr, while it were 4.35, 3.54, 3.11 and $2.53 \mathrm{kWhkg}^{-1}$ for Mawi bread at speeds 1.18,1.97, 2.40 and $3.55 \mathrm{~ms}^{-1}$, respectively. The results also indicated that the total costs of baking stage per $1 \mathrm{~kg}$ of bread baking stage were 1.14, 0.86, 0.71 and $0.59 \mathrm{LE} \mathrm{kg}^{-1}$ for Magr while it were 1.34, 0.98, 0.82and $0.71 \mathrm{LE} \mathrm{kg}^{-1}$ for Mawi bread, respectively at the same speeds.

Keywords: Energy Requirements, Baking time, Productivity, Moisture Content, Baladi-Bread

\footnotetext{
* Administrator of Agric. Eng. Dep., Fac. of Agric., Benha Univ., Egypt

** Professor. of Agric. Eng., Fac. of Agric., Benha Univ., Egypt

*** Lecturer. of Agric. Eng., Fac. of Agric., Benha Univ., Egypt

P.O. Box 13736, Egypt
} 


\section{INTRODUCTION}

$\mathrm{E}$ nergy sources include oil, electricity and woodchip burners. Previous studies in the baking industry estimate that the specific energy consumption of a bread oven is typically anywhere between 0.5 and $7.3 \mathrm{MJkg}^{-1}$ production depending on specific products and operating conditions. In this sense, baking is similar to (conventional) drying, both demanding a high amount of energy in comparison with chilling, freezing, and canning, which need less than $1 \mathrm{MJkg}^{-1}$ (Le Bail et al., 2010 and Purlis, 2012).

Thermal treatment of food targets two key objectives: cooking and safety. Bread baking and drying are similar in terms of energy demand with around $5 \mathrm{MJkg}^{-1}$ in the case of bread baking (Dinçer, 1997; Fellows, 1996).

An experiment was carried out to evaluate energy consumption in different types of bread baking (thermal, human and electrical). The thermal energy represented the most energy consumed, where, it represented $98.38-98.54 \%$ of the total energy consumed in bread baking stages. Human energy represented from $0.18-0.22 \%$ and electrical energy represented from 1.24-1.42\% of the total energy consumed in bread baking. The total costs of different types of baked bread were 2.32, 1.76 and 4.80 $\mathrm{LE} \mathrm{kg}^{-1}$ for Magr baladi, Mawi baladi and French breads, respectively (El-Adlyet al., 2015; Khater and Bahnasawy, 2014).

Jekayinfa (2007) revealed that bread-baking with wood as energy source required the highest energy $\left(6.15 \mathrm{kJmin}^{-1}\right)$ compared with $3.37 \mathrm{kJmin}^{-1}$ and $1.52 \mathrm{kJmin}^{-1}$ obtained with gas and electricity as sources of energy respectively. The cost of energy per $\mathrm{kg}$ of baked bread was N7.58 (\$ 0.059 ) with cooking gas as the energy source followed by N6.05 (\$ 0.047) for electricity and N5.05 (\$0.04) for wood in that order. The average baking rate using firewood, gas and electricity as energy sources were $11.92 \mathrm{kgh}^{-1}, 17.97 \mathrm{kgh}^{-1}$ and $20.58 \mathrm{kgh}^{-1}$ respectively.

Baking is an energy-intensive process due to water evaporation occurring in the product (latent heat of water vaporization is $2.257 \mathrm{MJkg}^{-1}$ at 100 ${ }^{\circ} \mathrm{C}$ ). The energy demand for a conventional baking process is around 3.7 $\mathrm{MJkg}^{-1}$, though it can be higher (up to $7 \mathrm{MJkg}^{-1}$ ) depending on specific products and operating conditions. In this sense, baking is similar to 
(conventional) drying, both demanding a high amount of energy in comparison with chilling, freezing, and canning, which need less than 1 $\mathrm{MJkg}^{-1}$ (Le Bail et al., 2010).

There are approximately 18,000 baladi bakeries in Egypt. The Egyptian Ministry of Finance estimates that approximately 12-13 billion LE is spent per year on subsidizing baladi bread and flour(World Bank, 2010). Most ovens use gas or diesel. There is a two-part fuel subsidy system: a standard subsidy and a special bakery subsidy. The latter is used to help ensure that the bakeries can make a profit, given that the price of a loaf of baladi bread has remained fixed at 5 piasters for 17 years. If the second subsidy was not in place, the government would need to either increase the price of bread or decrease the price of flour to achieve the same result (World Bank, 2010).

Studying the energy requirements of baladi-bread is very vital in baking industry, which suffers of the imprecision determinations of the costs required for bread-production. Moreover, there was an increase in energy costs which requires searching on the best way to save energy during bread-baking process stage. Also to obtain a reliable database regarding the baking energy at different oven operational parameters. Based on the results obtained by El-Adlyet al.(2015) which concluded that baking stage was the most consumable energy in bread baking, therefore, the main aim of the present work is to study and evaluate energy requirements baking stage at different oven belt speeds and different types of baladi-breads which considered the common types in Egypt especially in villages.

\section{MATERIALS AND METHODS.}

The experiment was carried out at a local bakery oven, Moshtohor, Toukh, Kalubia Governorate, Egypt, during the season of 2016 to determine the energy requirements of baking stage of two different types of baladi-breads, namely, Magr and Mawi at different belt speeds.

\subsection{Materials:}

\subsubsection{Ingredients used in baladi-bread}

The bread ingredients of these types are shown in table (1). 
Table (1):Bread ingredients of two types of baladi-breads.

\begin{tabular}{|c|c|c|}
\hline \multirow{2}{*}{ Ingredients } & \multicolumn{2}{|c|}{ Baladi bread } \\
\cline { 2 - 3 } & Magr & Mawi \\
\hline Flour(kg) & 50 & 50 \\
\hline Water(litter) & 33 & 75 \\
\hline Yeast(g) & 400 & 400 \\
\hline Salt(g) & 400 & 400 \\
\hline
\end{tabular}

Samples were prepared using a standard recipe for French bread: wheat flour $(100 \%)$, water $(54.1 \%)$, salt (1.6\%), sugar (1.6\%), margarine (1.6\%), and dry yeast $(1.2 \%)$. Dough was made by mixing the ingredients for $10 \mathrm{~min}$ in a home multi-function food processor at constant speed. Then individual samples of 100-150 g (cylindrical shape, ca. $0.15 \mathrm{~m}$ length, $0.04 \mathrm{~m}$ diameter) were formed and placed in a perforated tray. After $1.5 \mathrm{~h}$ proving at ambient temperature, samples duplicated their volume (Purliset al., 2009) .

Water and flour are the most significant ingredients in a bread recipe, as they affect texture and crumb the most. Flour (14.5\% moisture, 13\% protein, $0.55 \%$ ash, pH 5.7-6.1, Zanoniet al.,1993) is always 100\%, and the rest of the ingredients are a percent of that amount by weight. Approximately $50 \%$ water results in a finely textured, light bread. Most artisan bread formulas contain anywhere from $60 \%$ to $75 \%$ water. In yeast breads, the higher water percentages result in more $\mathrm{CO}_{2}$ bubbles, and a coarser bread crumb. According to $100 \%$ flour rest of the ingredients will be in following measurements like leavening agent yeast $2 \%$, sugar $4 \%$, salt $2 \%$ and shortening agent (ghee or mar-garine) 3\% (Mondal and Datta,2008).

\subsubsection{Description of oven components of baking stage:}

Fig. (1) shows the oven components which consists of the belt, motor, inverter, frontal fuel tank, frontal nozzel and burner, chimney, oven wall, rearward fuel tank, and rearward nozzel and burner. The belt is driven by $1.5 \mathrm{hp}$ motor and having a gear box to control the belt speed depending on the load and the output of the inverter. The belt feeding rate was 50 loaves. The dimensions of the belt are $5^{*} 0.83 \mathrm{~m}$ for length and width. The oven dimensions are $5 * 2 * 1.77 \mathrm{~m}$ for length, height and width. 
PROCESS ENGINEERING

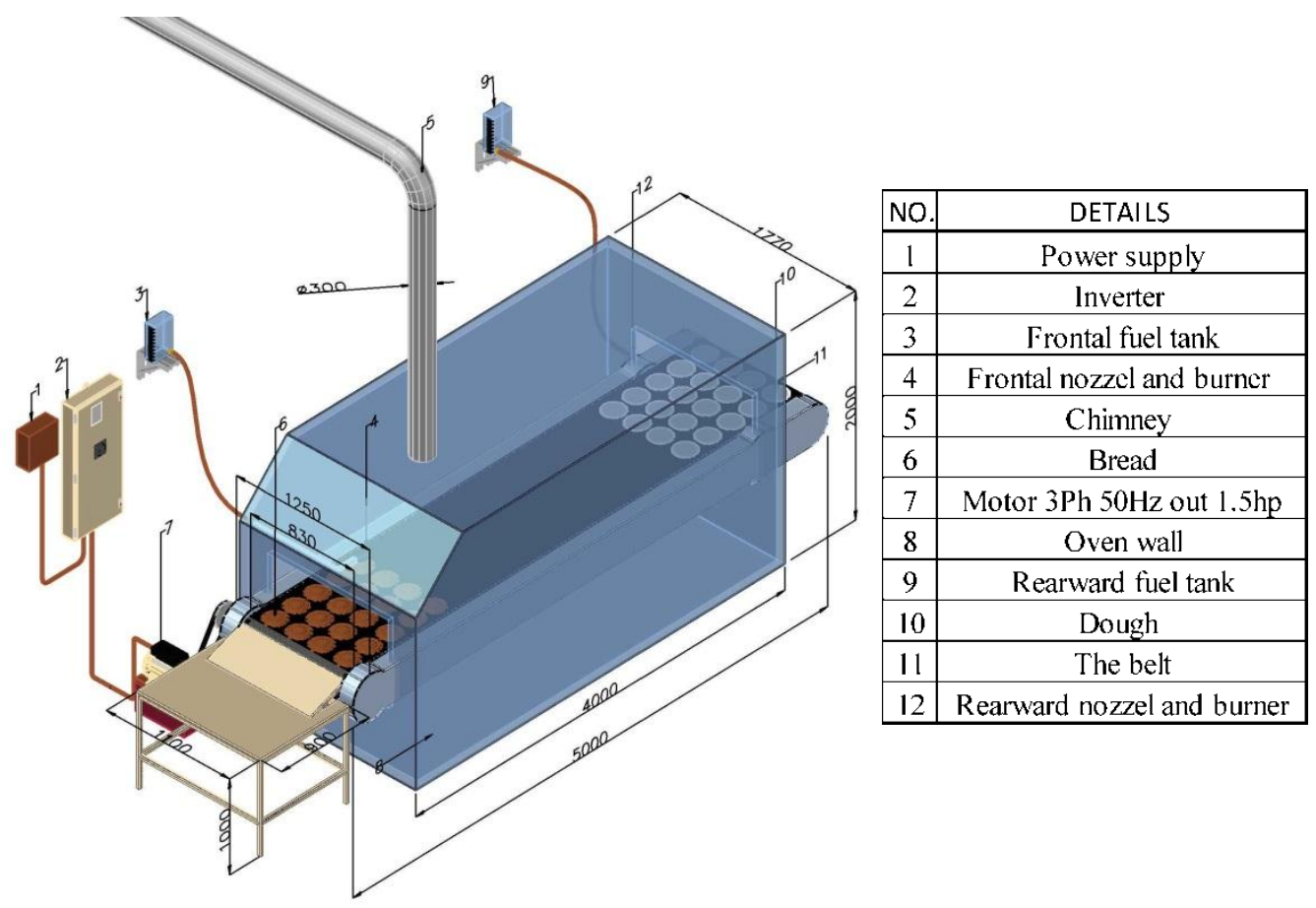

Dimensions in $\mathrm{mm}$

Figure (1): Schematic diagram of the oven components of the bakery

\subsubsection{Measuring devices and tools:}

The following measuring devices were used in this study:

- Inverter was used to control the electricity input of the belt motor (model IP65 (IEC-60529) NEMA-4 and 230v 50/60 Hz phase output 0 - v 3 phase $5 \mathrm{hp} / 4 \mathrm{~kW}$ - KWAIT).

- The clamp meter was used to determine the power requirement (kW) by recording the voltage and current strength (Model DT266 - Measuring range 200/1000A and 750/1000V with an accuracy of \pm 0.01 , China) to measure the line current strength (I) and the potential difference value (V).

- Mobile stopwatch with $1 / 100 \mathrm{~s}$ accuracy was used to record the time spent during baking process.

- A measuring cylinder for quantifying the amount of fuel consumed during bread-baking operations. 
- Graduated flask to make calibration for fuel.

- Digital balance.

\subsection{Methods:}

\subsubsection{Power requirements determination:}

The energy requirements of two types of baladi-bread baking namely, Magr and Mawi bread were determined at belt speeds of 1.18, 1.97, 2.40 and $3.55 \mathrm{~ms}^{-1}$.There are three types of power requirements, namely thermal energy, electrical energy and human energy. Fuel consumption was determined by using a graduated flask at speed treatments. Each treatment required $50 \mathrm{~kg}$ flour to obtain around 600 loaves. Recording the voltage and current strength to measure electrical energy. Recording number of persons to measure human energy. Moisture content, time, productivity of bread and power requirements were determined for each treatment. Each treatment was replicated 3 times and the average was taken.

\subsection{Measurements and determinations:}

\subsubsection{Machine productivity:}

It is the product mass/time, $\mathrm{kg} / \mathrm{h}$.

\subsubsection{Power requirements:}

The total power requirement (electrical, human and thermal) for oven component was calculated for the production of finished bread baking for two types of baladi-bread baking. The procedures used could be explained as follows:

Electrical power requirement was estimated from the measured electric current and voltage values and estimated according to Kurt (1979) as follows:

$$
E_{p}=\frac{\sqrt{3} \times I \times V \times \eta \times \cos \varphi}{1000}
$$

Where:

$$
\begin{aligned}
& \mathrm{E}_{\mathrm{p}} \quad \text { is the electrical energy, } \mathrm{kW} \\
& I \quad \text { is the electric current, Amperes. }
\end{aligned}
$$


$\eta \quad$ is the mechanical efficiency assumed to be 0.95(Metwally, 2010).

$V \quad$ is the electrical voltage, $\mathrm{V}$

$\cos \varphi \quad$ is the power factor being equal to 0.84

According to Odigboh (1997), at the maximum continuous energy consumption rate of $0.30 \mathrm{~kW}$ and conversion efficiency of $25 \%$, the physical power output of a normal human labor in tropical climates is approximately $0.075 \mathrm{~kW}$ sustained for an $8-10 \mathrm{~h}$ workday. This was calculated mathematically as:

$$
E_{m}=0.075 N
$$

Where:

$\mathrm{E}_{\mathrm{m}} \quad$ is the human power, $\mathrm{kW}$

$\mathrm{N} \quad$ is the number of persons involved in an operation.

Thermal power requirement was estimated from equation:

$$
E_{T}=m \times h v
$$

Where:

$\mathrm{E}_{\mathrm{t}} \quad$ is the thermal energy, $\mathrm{kW}$

$\mathrm{m}$ is the mass flow rate, $\mathrm{kg} \mathrm{s}^{-1}$

hv is the heating value of diesel, $42000 \mathrm{~kJ} \mathrm{~kg}^{-1}$ (Shahinet al., 2008)

The specific energy consumption was estimated by using the following equation:

Thespesificenergyconsumption $(\mathrm{kW} . \mathrm{hkg})=\frac{\text { Totalpower requirement }(\mathrm{kW})}{\text { Productivity }}$

\subsubsection{Statistical analysis:}

The statistical analysis for the data obtained was done according to Snedecor and Cochran (1980) and the treatments were compared using Least Significant Differences (LSD) test at 95\% confidence level (Gomez, 1984).

\subsubsection{Total operation costs:}

Hourly cost is calculated according to the equation that is given by Awady (1978) as follows: 


$$
C=\frac{p}{h}\left(\frac{1}{a}+\frac{i}{2}+t+r\right)+(\mathrm{w} \times \mathrm{e})+\frac{\mathrm{m}}{\mathrm{k}}
$$

Where:
$\mathrm{C}$ is the hourly cost, $\mathrm{LE} \mathrm{h}^{-1}$
$\mathrm{p} \quad$ is the price of the equipment, LE
$h \quad$ is the year by working hours, $h$
a is the life expected of the machine, year
I is the Interest rate, \%
$\mathrm{t}$ is the taxes and over heads ratio, $\%$
$\mathrm{r} \quad$ is the repair and maintenance ratio, $\%$
$\mathrm{w}$ is the power of motor in, $\mathrm{kW}$
e is the electricity cost, $\mathrm{LEkW}^{-1} \mathrm{~h}^{-1}$
$\mathrm{m} \quad$ is the operator monthly salary, LE.
$\mathrm{K} \quad$ is the monthly average working hours.
Cost inputs are listed in table (2).

Table (2): Cost inputs.

\begin{tabular}{|c|c|}
\hline Items & Oven baking \\
\hline Price of equipment, LE. & 24000 \\
\hline Motor, kW & 1.5 \\
\hline Life expected, year & 10 \\
\hline Taxes, \% & 3 \\
\hline Repair, \% & 10 \\
\hline Interest, \% & 10 \\
\hline Labors, $\mathrm{LE} \mathrm{h}^{-1}$ & 10 \\
\hline
\end{tabular}

\section{RESULTS AND DISCUSSIONS}

This work focus on the effect of oven belt speeds on the baking energy requirements of two types of baladi-bread baking. Moisture content of bread, baking time, productivity and power requirement were determined at different belt speeds.

\subsection{Moisture content}

Table (3) and fig. (2) show the average moisture content of two types of baladi-bread (Magr and Mawi) that baked at different belt speeds. The results indicated that the average moisture content of bread increased with increasing speed of belt, where it increased from 24.32 to $29.25 \%$ when 
the belt speed increased from 1.18 to $3.55 \mathrm{~ms}^{-1}$ for Magr bread. Meanwhile, it increased from 34.25to $41.66 \%$ when the belt speed increased from 1.18 to $3.55 \mathrm{~ms}^{-1}$ for Mawi bread.

The results indicated that the Mawi bread had more moisture content compared to Magr bread, where it was $34.25 \%$ compared to $24.32 \%$ at $1.18 \mathrm{~ms}^{-1}$ belt speed, $39.50 \%$ compared to $24.61 \%$ at $1.97 \mathrm{~ms}^{-1}$ belt speed, $40.98 \%$ compared to $26.09 \%$ at $2.40 \mathrm{~ms}^{-1}$ belt speed and $41.66 \%$ compared to $29.25 \%$ at $3.55 \mathrm{~ms}^{-1}$ belt speed which could be attributed to the initial moisture content of dough was $42.12 \%$ for Magr bread but was $62.02 \%$ for Mawi bread.

The results indicated that the average moisture content ranged from 24.32 to 29.25 and 34.25 to $41.66 \%$ for Magr and Mawi breads, respectively.

Table (3): Effect of belt speed on the average moisture content of two different types of baladi-breads.

\begin{tabular}{|c|c|c|}
\hline \multirow{2}{*}{$\begin{array}{c}\text { Speed of belt, } \\
\mathrm{m} \mathrm{s}^{-1}\end{array}$} & \multicolumn{2}{|c|}{ Average moisture content after baking, $(\%)$} \\
\cline { 2 - 3 } & Magr & Mawi \\
\hline 1.18 & 24.32 & 34.25 \\
\hline 1.97 & 24.61 & 39.50 \\
\hline 2.40 & 26.09 & 40.98 \\
\hline 3.55 & 29.25 & 41.66 \\
\hline
\end{tabular}

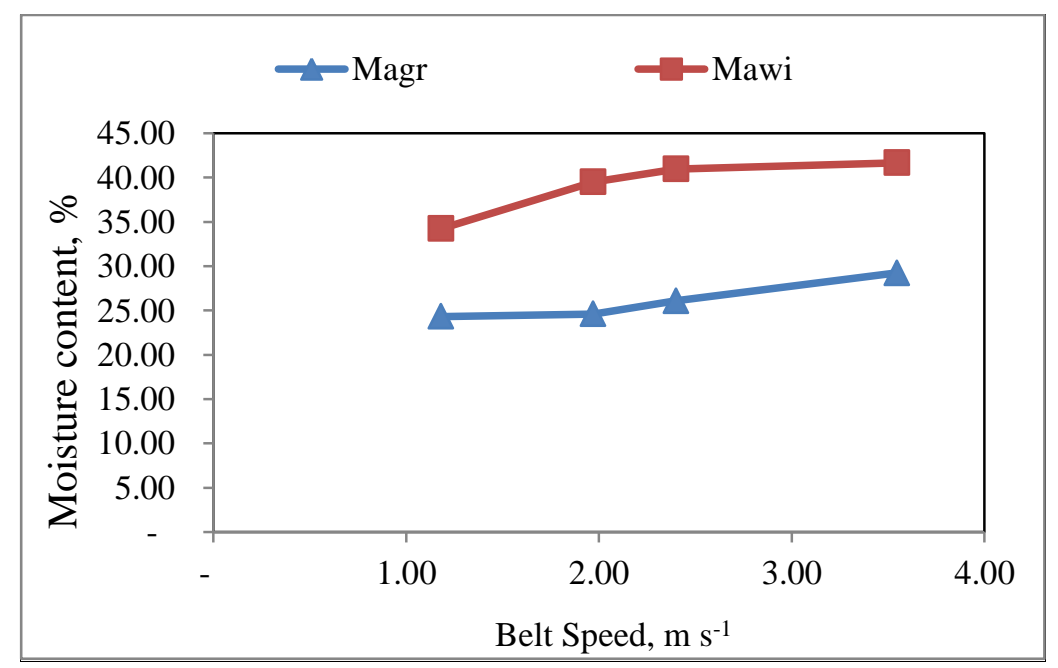

Figure (2): Effect of speed of belt on moisture content of two different types of baladi-breads. 
Regression analysis was carried out to find a relationship between belt speed $\left(1.18-3.55 \mathrm{~ms}^{-1}\right)$ and moisture content of two different types of bread. The most appropriate forms obtained were as follows:

$$
\begin{array}{ll}
\text { M.C } C_{1}=22.96\left(S_{B}\right)^{0.165} \text { for Magr bread } & R^{2}=0.808 \\
\text { M.C }_{2}=33.99\left(S_{B}\right)^{0.183} \text { for Mawi bread } & R^{2}=0.886
\end{array}
$$

Where

M.C : $_{1}$ is the moisture content of Magr bread, $\%$

M. $\mathrm{C}_{2}$ : is the moisture content of Mawi bread, \%

$\mathrm{S}_{\mathrm{B}}:$ is the baking belt speed (1.18-3.55), $\mathrm{m} / \mathrm{s}$

\subsection{Baking time:}

Table (4) and fig (3) show the baking time of two types of baladi-bread (Magrand Mawi) at different ovens belt speeds. It could be seen that the time of baking for one $\mathrm{kg}$ of bread decreased with increasing speed of belt, where it decreased from 1.65 to $0.81 \mathrm{~min}$ and 1.87 to 0.84 minfor Magrand Mawi bread, respectively when the belt speed increased from 1.18 to $3.55 \mathrm{~ms}^{-1}$.

The results indicated that the Mawi bread recorded higher time for baking compared to Magr bread, where it takes $1.87 \mathrm{minkg}^{-1}$ compared to $1.65 \mathrm{minkg}^{-1}$ at $1.18 \mathrm{~ms}^{-1}$ belt speed, which could be attributed to the higher initial moisture content of Mawi bread meanwhile, it takes nearly the same time at $3.55 \mathrm{~ms}^{-1}$ belt speed.

The results show that the time of baking at lower speed $\left(1.18 \mathrm{~ms}^{-1}\right)$ was 2 times of that required at the higher speed $\left(2.40\right.$ and $\left.3.55 \mathrm{~ms}^{-1}\right)$, which means using the higher speed could increase the bread productivity.

Table (4): Effect of speed of belt on baking time of two different types of baladi-bread

\begin{tabular}{|c|c|c|}
\hline \multirow{2}{*}{$\begin{array}{c}\text { Belt speed, } \\
\mathrm{m} \mathrm{s}^{-1}\end{array}$} & \multicolumn{2}{|c|}{ Average baking time,minkg } \\
\cline { 2 - 3 } & Magr & Mawi \\
\hline 1.18 & $1.65^{\mathrm{a}}$ & $1.87^{\mathrm{a}}$ \\
\hline 1.97 & $1.10^{\mathrm{a}}$ & $1.13^{\mathrm{b}}$ \\
\hline 2.40 & $0.86^{\mathrm{b}}$ & $0.89^{\mathrm{c}}$ \\
\hline 3.55 & $0.81^{\mathrm{b}}$ & $0.84^{\mathrm{c}}$ \\
\hline LSD at 0.05 & 0.06960 & 0.1476 \\
\hline
\end{tabular}


The statistical analysis showed that there were non-significant differences between speed 1.18 and $1.97 \mathrm{~ms}^{-1}$ treatmentsand the differences between 2.40 and $3.55 \mathrm{~ms}^{-1}$ were non-significant, while differences between speed $1.18,1.97 \mathrm{~ms}^{-1}$ and $2.40,3.55 \mathrm{~ms}^{-1}$ were significant for Magr, but there were significant differences between speed $\left(1.18\right.$ and $\left.1.97 \mathrm{~ms}^{-1}\right),(1.18$ and $\left.2.40 \mathrm{~ms}^{-1}\right),\left(1.97\right.$ and $\left.2.40 \mathrm{~ms}^{-1}\right)$ and $\left(1.18\right.$ and $\left.3.55 \mathrm{~ms}^{-1}\right)$, while it there were non-significant differences between speed $\left(2.40\right.$ and $3.55 \mathrm{~ms}^{-1}$ ) for Mawi bread.

It is worthy to mention that using $2.40 \mathrm{~ms}^{-1}$ belt speed gave almost the same result of using $3.55 \mathrm{~ms}^{-1}$ belt speed in terms of baking time where indicate that using $2.40 \mathrm{~ms}^{-1}$ belt speed is preferred to save energy.

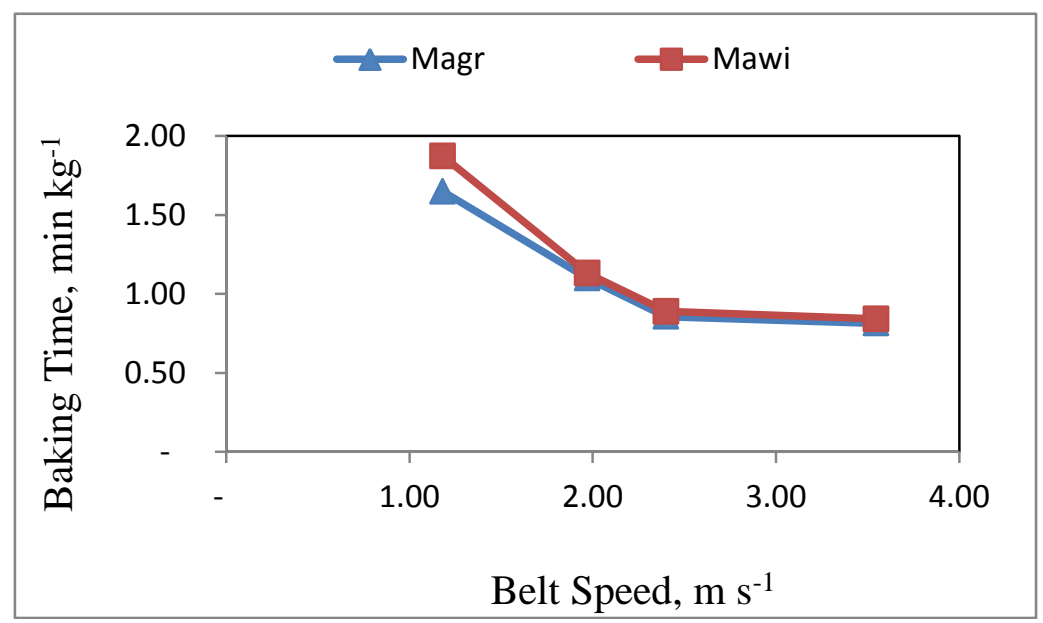

Figure (3): Effect of speed of belt on baking time of two different types of baladi-breads.

Regression analysis was carried out to find a relationship between belt speed (1.18-3.55 $\mathrm{ms}^{-1}$ ) and time of baking of two different types of breads. The most appropriate forms obtained were as follows:

$$
\begin{array}{lll}
\mathrm{T}_{\mathrm{B} 1}=1.753\left(\mathrm{~S}_{\mathrm{B}}\right)^{-0.67} & \text { for Magr bread } & \mathrm{R}^{2}=0.915 \\
\mathrm{~T}_{\mathrm{B} 2}=1.979\left(\mathrm{~S}_{\mathrm{B}}\right)^{-0.76} & \text { for Mawi bread } & \mathrm{R}^{2}=0.908
\end{array}
$$

Where:

$\mathrm{T}_{\mathrm{B} 1}$ : is the baking time of Magr bread, $\operatorname{minkg}^{-1}$

$\mathrm{T}_{\mathrm{B} 2}$ : is the baking time of Mawi bread, minkg $^{-1}$ 
$\mathrm{S}_{\mathrm{B}}: \quad$ is the baking belt speed $(1.18-3.55), \mathrm{ms}^{-1}$

\subsection{Productivity}

Table (5) and fig. (4) show the average oven productivity of two types of baladi-breads (Magrand Mawi) at different belt speeds. It could be seen, the average productivity of the oven increased with increasing belt speed, where it increased from 36.54 to $73.80 \mathrm{kgh}^{-1}$ and32.62to $71.33 \mathrm{kgh}^{-1}$ when the belt speed increased from 1.18 to $3.55 \mathrm{~ms}^{-1}$ for Magr and Mawi breads, respectively.

The results indicated that the oven productivity of Magr bread was higher than that of the Mawi productivity, where it was 36.54, 54.63, 70.11 and $73.80 \mathrm{kgh}^{-1}$ for Magr compared to 32.62, 53.10, 67.48 and $71.33 \mathrm{kgh}^{-1}$ for Mawi at 1.18, 1.97, 2.40 and $3.55 \mathrm{~ms}^{-1}$ belt speed, respectively.

The results show that productivity at higher speed $\left(3.55 \mathrm{~ms}^{-1}\right)$ was twice of that produced at the lower speed $\left(1.18 \mathrm{~ms}^{-1}\right)$, which means using the higher speed could increase the bread productivity.

Table (5): Effect of speed of belt on the average oven productivity of two different types of baladi-breads.

\begin{tabular}{|c|c|c|}
\hline \multirow{2}{*}{$\begin{array}{c}\text { Belt speed } \\
\mathrm{m} \mathrm{s}^{-1}\end{array}$} & \multicolumn{2}{|c|}{ Average productivity, $\mathrm{kgh}^{-1}$} \\
\cline { 2 - 3 } & Magr & Mawi \\
\hline 1.18 & $36.54^{\mathrm{d}}$ & $32.62^{\mathrm{d}}$ \\
\hline 1.97 & $54.63^{\mathrm{c}}$ & $53.10^{\mathrm{c}}$ \\
\hline 2.40 & $70.11^{\mathrm{b}}$ & $67.48^{\mathrm{b}}$ \\
\hline 3.55 & $73.80^{\mathrm{a}}$ & $71.33^{\mathrm{a}}$ \\
\hline LSD at 0.05 & 1.968 & 2.771 \\
\hline
\end{tabular}

The statistical analysis showed that there were significant differences between all speeds for both Magr and Mawi bread. It could be concluded that using the highest speed gave the highest production where indicate that using $3.55 \mathrm{~ms}^{-1}$ belt speed is preferred to get on save energy high production. 


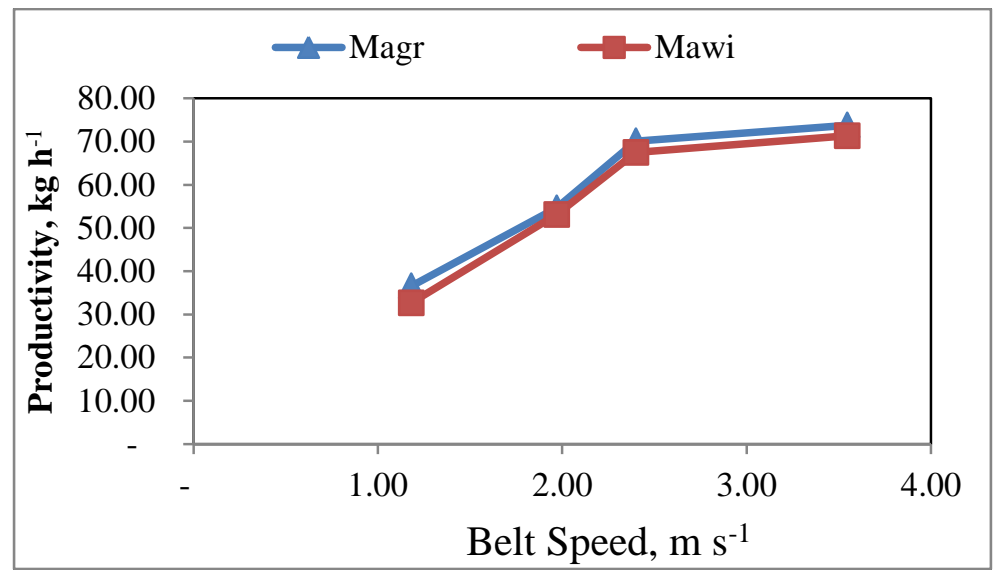

Figure (4): Effect of speed of belt on average productivity of two different types of baladi-bread.

Regression analysis was carried out to find a relationship between belt speed (1.18-3.55ms $\left.{ }^{-1}\right)$ and average productivity of two different types of bread. The most appropriate forms obtained were as follows:

$$
\begin{array}{ll}
\mathrm{Pro}_{1}=34.32\left(\mathrm{~S}_{\mathrm{B}}\right)^{0.672} \text { for Magr bread } & \mathrm{R}^{2}=0.917(10) \\
\mathrm{Pro}_{2}=30.83\left(\mathrm{~S}_{\mathrm{B}}\right)^{0.743} \text { for Mawi bread } & \mathrm{R}^{2}=0.910(11)
\end{array}
$$

Where:

$\mathrm{Pro}_{1}$ : is the productivity of Magr bread, $\mathrm{kgh}^{-1}$

$\mathrm{PrO}_{2}$ : is the productivity of Mawi bread, $\mathrm{kgh}^{-1}$

$\mathrm{S}_{\mathrm{B}}: \quad$ is the baking belt speed (1.18-3.55), $\mathrm{ms}^{-1}$

\subsection{Energy requirements for baking stage:}

There are three types of energy requirements which included electrical, human and thermal energies as shown in table (6) and fig (5), where it shows the specific energy requirements in baking stage of two different types of baladi bread at different belt speeds. It could be seen that the specific energy consumed in bread baking stage were 3.57, 2.92, 2.54 and $1.93 \mathrm{kWhkg}^{-1}$ for Magr at speeds 1.18, 1.97, 2.40 and $3.55 \mathrm{~ms}^{-1}$, while they were $4.35,3.54,3.11$ and $2.53 \mathrm{kWhkg}^{-1}$ for Mawi bread at the same speeds, respectively. The highest values of specific energy consumed (3.57 and4.35 kWhkg-1) were found at $1.18 \mathrm{~ms}^{-1}$ belt speed for Magr and Mawi bread .These results agreed with those obtained by Grönroos $\boldsymbol{e t}$ al. (2006) whose found that the energy consumption for rye bread (organic and conventional)were3.72and $4.28 \mathrm{kWh} \mathrm{kg}^{-1}$ of bread, respectively, 
meanwhile the lowest values of energy consumed (1.93 and $2.53 \mathrm{kWhkg}^{-}$ ${ }^{1}$ ) were found at $3.55 \mathrm{~ms}^{-1}$ belt speed for Magr and Mawi, respectively. These results also agreed with those obtained by Le Bail et al. (2010)whose found that the energy consumption of a bread is typically anywhere between 0.5 and $7.3 \mathrm{MJ} \mathrm{kg}^{-1}$ production $(0.14$ and $2.044 \mathrm{kWh}$ $\left.\mathrm{kg}^{-1}\right)$ and it can be higher up to $7 \mathrm{MJ} \mathrm{kg}^{-1}\left(2.044 \mathrm{kWh} \mathrm{kg}^{-1}\right)$ depending on specific products and operating conditions.

Table (6): The specific energy requirements for baking stage of two different types of baladi-bread at different belt speeds.

\begin{tabular}{|c|c|c|}
\hline \multirow{2}{*}{$\begin{array}{c}\text { Belt speed, } \\
\mathrm{m} \mathrm{s}^{-1}\end{array}$} & \multicolumn{2}{|c|}{$\begin{array}{c}\text { The specific energy requirement for baking } \\
\text { stage, } \mathrm{kWhkg}^{-1}\end{array}$} \\
\cline { 2 - 3 } & Magr & Mawi \\
\hline 1.18 & 3.57 & 4.35 \\
\hline 1.97 & 2.92 & 3.54 \\
\hline 2.40 & 2.54 & 3.11 \\
\hline 3.55 & 1.93 & 2.53 \\
\hline
\end{tabular}

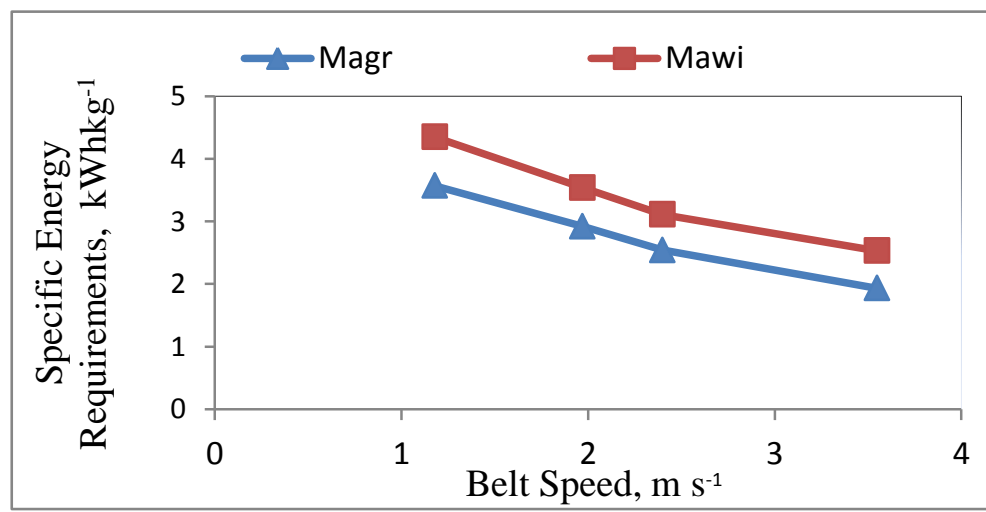

Fig. (5): The specific energy requirements for baking stage of two different types of baladi-breads at different belt speeds.

Regression analysis was carried out to find a relationship between belt speed (1.18-3.55 $\left.\mathrm{ms}^{-1}\right)$ and energy requirements for baking stage of two different types of baladi-breads. The most appropriate forms obtained were as follows:

$$
\begin{aligned}
& \mathrm{SER}_{1}=4.049\left(\mathrm{~S}_{\mathrm{B}}\right)^{-0.55} \text { for Magr breadR }{ }^{2}=0.973 \\
& \mathrm{SER}_{2}=4.798\left(\mathrm{~S}_{\mathrm{B}}\right)^{-0.49} \text { for Mawi breadR }=0.990(13)
\end{aligned}
$$

Where:

$\mathrm{SER}_{1}$ : is the specific energy requirements of Magr bread, $\mathrm{kWhkg}^{-1}$ 
$\mathrm{SER}_{2}$ : is the specific energy requirements of Mawi bread, $\mathrm{kWhkg}^{-1}$

$\mathrm{S}_{\mathrm{B}}: \quad$ is the baking belt speed (1.18-3.55), $\mathrm{ms}^{-1}$

\subsection{Totalcostsforbread baking:}

Table (7) and fig. (6) show the estimated costs of two different types of bread baking. It could be seen that the total costs for baking stagewere 1.14, 0.86, 0.71 and $0.59 \mathrm{LE} \mathrm{kg}^{-1}$ for Magr bread compared with 1.34, 0.98, 0.82 and $0.71 \mathrm{LE} \mathrm{kg}^{-1}$ for Mawi baladi bread at speeds 1.18, $1.97,2.40$ and $3.55 \mathrm{~ms}^{-1}$, respectively.

The results indicated that the Mawi bread recorded higher cost for baking stage compared to Magr bread, where it takes $1.34 \mathrm{LEkg}^{-1}$ compared to $1.14 \mathrm{LEkg}^{-1}$ at $1.18 \mathrm{~ms}^{-1}$ belt speed, which could be attributed to the higher initial moisture content of Mawi bread which took longer time.

The results show that the costs of baking stage at lower speed $\left(1.18 \mathrm{~ms}^{-1}\right)$ was 2 times of that required at the higher speed $\left(2.40\right.$ and $\left.3.55 \mathrm{~ms}^{-1}\right)$, which means using the higher speed could decrease the baking costs.

Table (7): Comparison between total costs of baking stage of two different types of baladi-bread.

\begin{tabular}{|c|c|c|}
\hline \multirow{2}{*}{$\begin{array}{c}\text { Speed of belt, } \\
\mathrm{ms}^{-1}\end{array}$} & \multicolumn{2}{|c|}{ Costs of baking stage,LEkg } \\
\cline { 2 - 3 } & Magr & Mawi \\
\hline 1.18 & 1.14 & 1.34 \\
\hline 1.97 & 0.86 & 0.98 \\
\hline 2.40 & 0.71 & 0.82 \\
\hline 3.55 & 0.59 & 0.71 \\
\hline
\end{tabular}

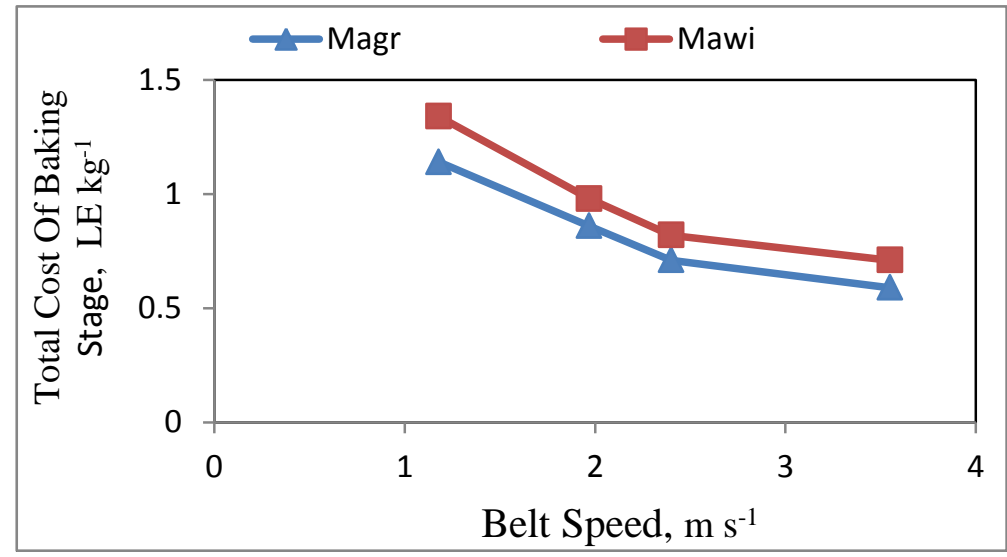

Fig. (6): Comparison between total costs of baking stage of two different types of baladi-bread. 
Regression analysis was carried out to find a relationship between belt speed (1.18-3.55 $\mathrm{ms}^{-1}$ ) and costs of baking stage of two different types of baladi-breads. The most appropriate forms obtained were as follows:

$$
\begin{array}{lll}
\text { T. } C_{1}=1.262\left(S_{B}\right)^{-0.61} & \text { for Magr bread } & R^{2}=0.988(14) \\
\text { T. } C_{2}=1.454\left(S_{B}\right)^{-0.59} & \text { for Mawi bread } & R^{2}=0.980(15)
\end{array}
$$

Where:

T. $C_{1}$ : is the total cost of baking stage of Magr bread, $\mathrm{LE} \mathrm{kg}^{-1}$

T. $C_{2}$ : is the specific energy requirements of Mawi bread, $\mathrm{LE} \mathrm{kg}^{-1}$

$\mathrm{S}_{\mathrm{B}}: \quad$ is the baking belt speed (1.18-3.55), $\mathrm{m} \mathrm{s}^{-1}$

\section{CONCLUSION}

This study successfully investigated the energy requirements of baking two types of baladi-breads, namely, Magr and Mawi at different belt speeds $\left(1.18,1.97,2.40\right.$ and $\left.3.55 \mathrm{~ms}^{-1}\right)$. The study results concluded that the specific energy consumed in bread baking were 3.57, 2.92, 2.54 and $1.93 \mathrm{kWhkg}^{-1}$ at belt speeds of $1.18,1.97,2.40$ and $3.55 \mathrm{~ms}^{-1}$, respectively for Magr bread, while it were 4.35, 3.54, 3.11 and $2.53 \mathrm{kWhkg}^{-1}$ for Mawi bread at the same speeds, respectively. Costs study revealed that baking stage costs per $1 \mathrm{~kg}$ of bread baking stage ranged from0.59-1.34 $\mathrm{LE} \mathrm{kg}^{-1}$ depending on type of bread and belt speed.

\section{REFERENCES}

Dinçer, A. 1997. Heat Transfer in Food Cooling Applications. Taylor \& Francis, NewYork, USA.

El-Adly, I.F., Khater, E.G., Bahnasawy, A.H., Ali, S.A.2015.Energyconsumption in bread baking. The $2^{\text {th }}$ Annual Conference of Misr Soc. of Agri.Eng.,12 December 2015:pp 535-554.

Fellows, P.J. 1996.Food Processing Technology Principles and Practice. Springer, Cambridge (Chapters 1:54-58, 15:314-327).

Gomez, K.A. 1984. Statistical procedures for agricultural research, $2^{\text {nd }}$ ed. John Wiely\&Sons, New York, USA 680 pp.

Grönroos, J., SeppälaJ.,Voutilainen P., Seuri P. and Koikkalainen K. 2006. Energy use in conventional and organic milk and rye 
bread production in Finland. Agriculture, Ecosystems and Environment, 117:109-118.

Jekayinfa, S. O. 2007. Ergonomic Evaluation and Energy Requirements of Bread baking Operations in South Western Nigeria. Agricultural Engineering International: the CIGR E journal. Manuscript EE 07 002. Vol. IX. June.

Khater, E. G, Bahnasawy, A. H., 2014. Heat and Mass Balance for Baking Process. Journal of Bioprocessing and Biotechniques, 2014, 4:7. http://dx.doi.org/10.4172/2155-9821.1000190

Kurt, G. 1979.Engineering formulas. $3^{\text {rd }}$. Ed. Mc Graw - Hill book Co.

Le Bail, A., Dessev, T., Jury, V., Zuniga, R., Park, T., Pitr off, M.

2010. Energy demand for selected bread making process: conventional versus part baked frozen technologies. Journal of Food Engineering, 96 (4): 510-519.

Metwally, K.A., 2010. Study the effect of some operational Factors on hammer mill. A MSc thesis of Department of Agricultural Engineering, Faculty of Agriculture, Zagazig University. Egypt.

Mondal, A and A. K. Datta. 2008. Bread baking-A review. Journal of Food Engineering, 86:465-474.

Odigboh, E. U. 1997. Machines for crop production. In: Stout BA, editor. Hand book of Agricultural Engineering-Plant Production Engineering. American Society of Agricultural Engineers.

Purlis, E. 2012. Baking process design based on modelling and simulation: Toward optimization of bread baking. . Food Control, 27:45-52.

Purlis, E. and V. O. Salvadori. 2009. Bread baking as a moving boundary problem. Part 1: Mathematical modeling. Journal of Food Engineering، 91:428-433.

Snedecor, G.W., Cochran W. G. 1980. Statistical Methods, $7^{\text {th }}$ Ed., Iowa State University Press, Ames, Iowa, USA. 
Shahin S., Jafari, A., Mobli, H., Rafiee, S., Karimi, M. 2008. Effect of Farm Size on Energy Ratio for Wheat Production: A Case Study from Ardabil Province of Iran American-Eurasian. J. Agric. \& Environ. Sci., 3 (4), 604-608.

World Bank, 2010. The cost efficiency in the production and distribution of subsidised bread in Egypt. Draft Report, World Bank, June, 2010.

\section{الملخص العربيى}

\section{متطلبات الطاقة فى مرحلة الخبز نتيجة تغيير سرعة السير ونوع الخبز} إسلام العادلى** ، عادل بهنساوى*** ، سمير على** ، السيد خاطر *** ه

تهدف هذه الدراسة الى تقدير الطاقة النوعية المستهلكة فى مرحله الخبزنتيجة التغيير فى سرعة

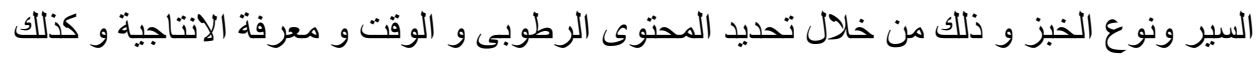

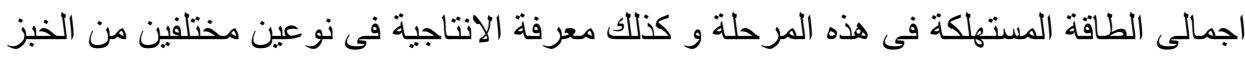

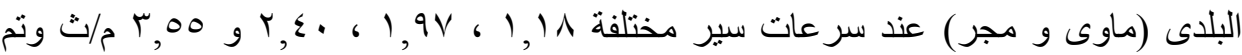

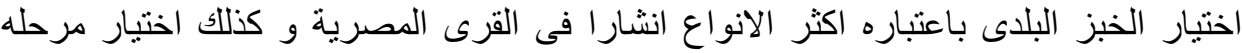

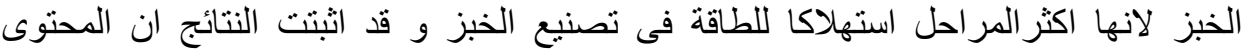

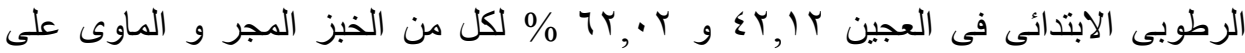

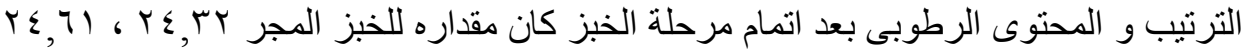

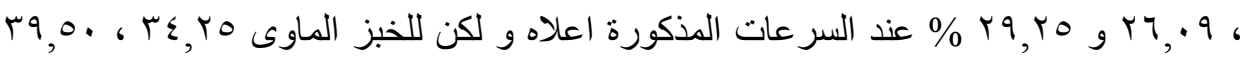
(

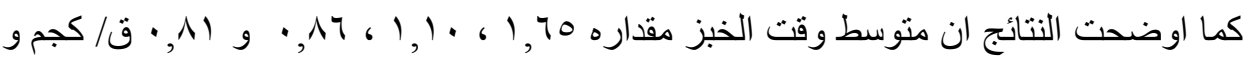

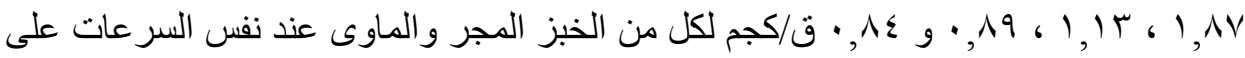

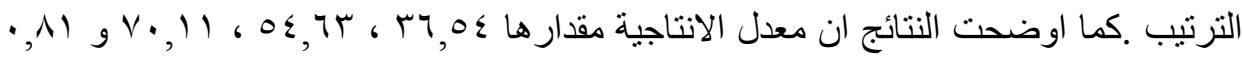

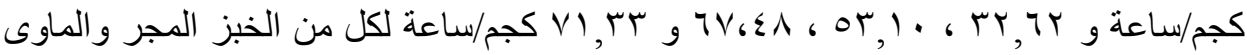

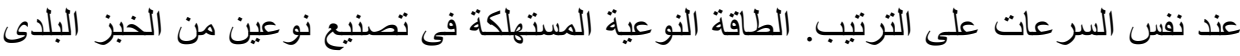

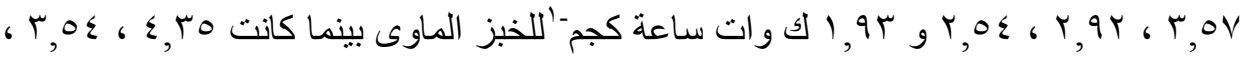

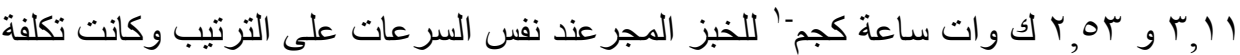

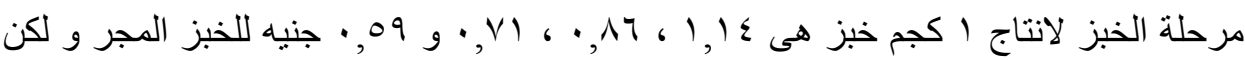

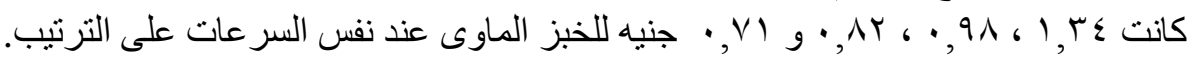

* معيدة الهندسة الزراعية ـ كلية الزراعة بمشتهر - جامعة بنها.

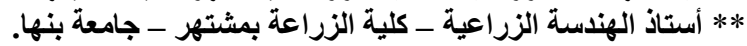

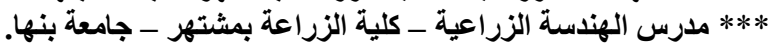

